iE : Jurnal Inspirasi Ekonomi

Vol 4 No. 2 Juni 2019 | Isssn: 2503-3123 (Online)

\title{
ANALISIS KINERJA KEUANGAN PT. BANK PEMBANGUAN DAERAH NUSA TENGGARA TIMUR TAHUN 2015-2017
}

\author{
Leopold Melkiano Triangga Dawu \\ leopolddawu@gmail.com \\ Prodi. Akuntansi Fakultas Ekonomika dan Bisnis \\ Universitas Katolik Widya Mandira Kupang
}

\begin{abstract}
ABSTRAK
PT. Bank Pembangunan Daerah Nusa Tenggara TImur merupakan bank pemerintah yang sebagian besar sahamnya dimiliki oleh Pemerintah Daerah Provinsi Nusa Tenggara Timur.Kinerja keuangan adalah satu aspekpenting dalam pencapaian Good Corporate Governance dalam perbankan Indonesia.Adanya transparansi diharapkan dapat meningkatkan kepercayaan publik terhadap perbankan nasional.Tujuan dari penelitian ini adalah untuk mengatahui kinerja keuangan dari Bank Pembangunan Daerah NTT tahun 2015-2017.Berdasarkan hasil perhitungan rasio, rasio likuiditas menunjukan bahwa PT. Bank NTT memiliki kinerja yang cukup baik, meski menunjukan tren penurunan likuiditas. Berkaitan dengan rasio Solvabilitas selama tiga tahun menunjukan kinerja yang baik juga yang artinya Pihak bank mampu membayar semua kewajibannya, dan untuk rasio Rentabilitas menunjukan bahwa selama tiga tahun PT. Bank NTT sudahbaik dalam melakukan efisiensi usaha dalam menghasilkan labanya.
\end{abstract}

Keyword: Bank, Kinerja Keuangan, Rasio 
iE : Jurnal Inspirasi Ekonomi

Vol 4 No. 2 Juni 2019 | Isssn: 2503-3123 (Online)

\title{
THE ANALISIS OF FINANCIAL PERFORMANCE OF PT. BANK PEMBANGUAN DAERAH OF EAST NUSA TENGGARA IN THE YEAR OF 2015-2017
}

\author{
Leopold MelkianoTrianggaDawu \\ leopolddawu@gmail.com \\ Accounting Study Program, Economics and Business Faculty \\ Catholic University WidyaMandira Kupang
}

\begin{abstract}
PT. Bank Pembangunan Daerah of East Nusa Tenggara is a government bank that more than half of its capital is owned by the Government of East Nusa Tenggara Province. Financial performance is one important aspect in order to obtainGood Corporate Governance in Indonesia's banking. The transparency is expected to increase the trust of public for national banking. The purpose of this research is to know the financial performance of Bank Pembangunan Daerah of East Nusa Tenggara Province in the year 2015-2017.Based on the ratio counting, liquidity ratio shows that PT. Bank NTT has satisfactory performance although the liquidity seems to lessen down. Regarding the solvability ratio for three years, it shows that it is in good condition which means the Bank is able to pay its entire obligation and the profitability ratio shows that for three years PT. Bank NTT is in good enough in doing its efforts for efficiency to get its profits.
\end{abstract}

Keyword: Bank, Financial Performance, Ratio 


\section{PENDAHULUAN}

Perkembangan kehidupan ekonomi masyarakat saat ini memberikan dampak pada pola pemikiran baru yang turut berkembang bersama dengan kemajuan zaman. Ketika mekanisme pembayaran dituntut untuk selalu mengakomodir setiap kebutuhan masyarakat dalam hal perpindahan dana secara cepat, aman dan efisien, maka inovasi-inovasi teknologi perbankan semakin bermunculan dengan sangat pesat. Dunia perbankan memberikan jawaban dengan berbagai fasilitas kemudahan dan semakin tiada batas.

Mengulas kegiatan Ekonomi tidak lepas dari dunia Perbankan, krisis perbankan tahun 1997/ 1998 memberikan pelajaran yang harus diperhatikan dalam bisnis perbankan.Bank kesulitan likuiditas, kualitas aset memburuk, tidak mampu menciptakan earning dan akhirnya modal terkuras dalam waktu yang sangat cepat, dan keadaan ini berlangsung cukup lama yaitu hingga tahun 2004.Kesulitan lembaga perbankan di Indonesia tampak berkepanjangan, padahal Bank Indonesia telah menjalankan tugasnya sebagai Lender of last resosrt.Istilah ini memaliki arti bahwa Bank Indonesi memiliki fungsi yang melekat sebagai pelindung bank dalam hal terjadi kesulitan likuiditas.Oleh karena itu, penting bagi semua lapisan masyarakat untuk mempelajari setiap aspek yang terkait dengan pelaku utama dalam sistem keuangan, yaitu perbankan.

Ukuran kinerja keuangan sejak zaman Orde Baru telah ditetapkan oleh pemerintah berdasarkan Keputusan Mentri Keuangan KEP.792/MK/IV/12?1970 tentang lembaga keuangan yang telah diubah dan diperbaharui dengan keputusan Mentri Keuangan No. 280/KMK/10/1989 tanggal 25 Maret 1989 tentang pengawasan dan pembinaan lembaga keuangan bukan bank serta ditindak lantuji dengan surat edaran Bank Indonesia No. SE.23/21/BPPP/1991 yang menyebutkan bahwa pengukuran kinerja lembaga keuangan dilihat dari aspek permodalan, kualitas aktiva produktif, aspek manajemen, rentabilitas dan likuiditas.

PT. Bank Pembangunan Daerah Nusa Tenggara TImur merupakan bank pemerintah yang sebagian besar sahamnya dimiliki oleh Pemerintah Daerah Provinsi Nusa Tenggara Timur sebesar 32,85\%, 20 Pemerintah Kabupaten sebesar 60,42\% dan satu pemerintah Kota sebesar 6,66\% serta sisanya 0,07 dimiliki oleh tiga orang pribadi yaitu mantan direktur utama sebesat $0,04 \%$, Lutre Octavianus Wila Huki 0,02\% dan Johan Christian Tallo sebesar 0,01\%. Bank Pembangunan Daerah NTT merupakan bank pemerintah yang mempunyai misi mendorong pertumbuhan ekonomi daerah dan perolehan laba yang optimal.bersasarkan data yang diperoleh laba BPD NTT tahun 2017 mengalami peningkatan sebesar Rp 12.391.421.005, dimana laba pada tahun $2016 \mathrm{Rp}$ 9597.926.603.279. Peningkatan laba dari tahun 
2015 sampai dengan 2017 tentunya akan berdampak baik untuk pikah bank, namun diperlukan analisis mendalam guna menggambarkan kinerja dari bank itu sendiri.

Berdasarkan latar belakang yang diuraikan di atas, maka rumusan masalah yang diangkat yaitu , Bagaimana kinerja keuangan Bank Pembangunan Daerah NTT tahun 2015-2017? Tujuan dari penelitian ini adalah untuk mengatahui kinerja keuangan dari Bank Pembangunan Daerah NTT tahun 2015-2017

\section{METODE}

Penelitian ini berlangsung selama tiga (3) bulan, dari bulan September sampai dengan November 2018.Penelitian ini dilakukan pada Bank Pembangunan Daerah NTT. Jenis data yang digunakan dalam penelitian ini adalah data sekunder, yaitu data melalui laporan keuangan yang diterbikan oleh PT. Bank Pembangunan NTT tahun 2015-2017 yang diperoleh dari Bank NTT berupa laporan laba rugi, neraca, laporan perubahan modal, laporan arus kas serta catatan atas laporan keuangan (CaLK). Teknik pengambilan data dapat dilakukan dengan metode dokumenter, kepustakaan dan dengan wawancara

Analisa data yang dilakukan dalam penelitian ini adalah analisa kinerja keuangan dengan menggunakan analisis rasio, yaitu rasio likuiditas, solvabilitas, dan rentabilitas selama 3 tahun yaitu tahun 2015-2017.

\section{PEMBAHASAN}

Melakukan analisis berbagai pos dan hubungannya pada suatu laporan keuangan merupakan dasar yang dapat digunakan untuk memberikan gambaran mengenai keadaan keuangan dan hasil operasi pada suatu perusahaan khususnya bank. Salah satu cara yang dapt digunakan untuk mengukur keadaan keuangan suatu bank dapat digunakan analisis rasio. Melakukan analisis berbagai pos dan hubungannya pada suatu laporan keuangan merupakan dasar yang dapat digunakan untuk menginterpretasikan keadaan keuangan dan hasil operasi pada suatu bank.

\section{Rasio Likuiditas/rasio lancar}

Rasio likuiditas digunakan untuk mengukur kemampuan bank dalammemenuhi kewajiban jangka pendeknya pada saat ditagih.

Selain itu juga rasio ini gunakan untuk mengetahui kemampuan bank dalam membayar kembali pencairan dana deposannya/nasabah pada saat ditagih serta dapat mencukupi permintaan kredit yang telah diajukan. 
Rasio ini untuk mengukur kemampuan bank dalam membayar kembali pencairan dana deposan/nasabah pada saat ditagih serta dapat mencukupi permintaan kredit yang telah diajukan oleh calon debitur. Rasio likuiditas terdiri dari:

\section{Rasio Cepat/Quick ratio}

Rasio ini adalah rasio yang digunakan untuk mengukur kemampuan bank dalam memenuhi kewajibannya terhadap para deposan (pemilik simpanan giro, tabungan dan deposito). Rasio ini bermanfaat untuk:Mengantisipasi dana yang diperlukan saat ada kebutuhan yang mendesak;Memudahkan nasabah yang ingin melakukan penaikan dana;Bagi bank untuk mendapat persetujuan investasi lain yang menguntungkan.

Quick ratio $=\frac{\text { cash assets }}{\text { total deposit }} \times 100 \%$

Tabel 1

Kas Bank Pembangunan Daerah NTT Tahun 2016-2017

\begin{tabular}{|l|l|l|l|}
\hline KAS dan Giro & \multicolumn{1}{|c|}{$\mathbf{2 0 1 5}$} & \multicolumn{1}{c|}{$\mathbf{2 0 1 6}$} & \multicolumn{1}{c|}{$\mathbf{2 0 1 7}$} \\
\hline Kas & 228.038 .519 .891 & 222.895 .183 .645 & 417.557 .848 .375 \\
\hline Giro Pada Bank Indonesia & 910.284 .094 .842 & 562.923 .209 .842 & 624.245 .494 .662 \\
\hline Giro Pada Bank Lain & 6.927 .801 .700 & 7.864 .404 .525 & 7.393 .552 .432 \\
\hline $\begin{array}{l}\text { Penyisihan Kerugian } \\
\text { Penurunan Nilai }\end{array}$ & $(25.400 .862)$ & $(25.400 .862)$ & $(25.400 .862)$ \\
\hline Jumlah Bersih & 6.902 .400 .838 & 7.839 .003 .663 & 7.368 .151 .570 \\
\hline $\begin{array}{l}\text { Penempatan Pada Bank } \\
\begin{array}{l}\text { Indonesia Dan Bank Lain } \\
\text { Jumlah(Kas Dan Giro) }\end{array}\end{array}$ & \begin{tabular}{l}
$\mathbf{1 . 8 8 9 . 7 6 0 . 7 0 2 . 1 9 9}$ \\
\hline
\end{tabular} & $\mathbf{1 . 5 6 8 . 0 2 2 . 8 0 4 . 6 1 8}$ & $\mathbf{1 . 6 6 4 . 0 4 9 . 6 3 5 . 3 4 9}$ \\
\hline
\end{tabular}

Sumber: Laporan Pelaksanaan Bank NTT, 2018

Berdasarkan tabel diatas apat dilihat bahwa aset PT. Bank NTT dari tahun 2015 sampai tahun 2017 secara umum perkembangannya fluktuatif dan cenderung menurun. Dari sisi kas mengalami peningkatan hingga tahun 2017.Selanjutnya ditampilkan data liabilitas tahun 2015 sampai 2017 guna menghitung rasio cepat.Manajemen kas merupakan bagian dari transaction banking dan corporate banking.

Manajemen kas merupakan solusi, yakni keseluruhan aktivitas yang diberikan untuk prusahaan dalam satu rangkaian.Solusi berbeda dengan aktivitas karena aktivitas hanya berupa satu kegiatan yang memiliki tujuan untuk memenuhi 
kebutuhan konsumen.Sedangkan solusi memiliki tujuan akhir untuk meningkatkan nilai dari pelanggan.

Tabel 2

Liabilitas Bank Pembangunan Daerah NTT Tahun 2015-2017

\begin{tabular}{|l|c|c|c|}
\hline & $\mathbf{2 0 1 5}$ & $\mathbf{2 0 1 6}$ & $\mathbf{2 0 1 7}$ \\
\hline LIABILITAS & & & 51.400 .541 .796 \\
\hline Liabilitas Segera & 69.669 .931 .557 & 106.998 .059 .627 & \\
\hline Simpanan Nasabah & & & 334.956 .375 .106 \\
\hline Pihak Berelasi & 939.197 .993 .275 & 377.112 .014 .485 & 6.677 .993 .637 .886 \\
\hline Pihak Ketiga & 6.342 .186 .611 .975 & 6.418 .150 .451 .699 & $\mathbf{7 . 0 1 2 . 9 5 0 . 0 1 2 . 9 9 2}$ \\
\hline Jumlah & $\mathbf{7 . 2 8 1 . 3 8 4 . 6 0 5 . 2 5 0}$ & $\mathbf{6 . 7 9 5 . 2 6 2 . 4 6 6 . 1 8 4}$ & $\mathbf{2}$ \\
\hline
\end{tabular}

Sumber: Laporan Pelaksanaan Bank NTT, 2018

Berdasarkan tabel di atas dapat dilihat bahwa jumlah leabilitas dari tahun 2015 sampai 2017 mengalami perkembangan fluktuatif dan cenderung menurun. Jika dilihat dari data pada tabel 1 dan 2 maka dapat dihitung rasio cepat. Rasio cepat dari tahun 2015-2017 sebagai berikut:

Tahun $2015=\frac{1.889 .760 .702 .199}{7.281 .384 .605 .250} \times 100 \%$

$$
=25,95 \%
$$

Tahun2016 $=\frac{1.568 .022 .804 .618}{6.795 .262 .466 .184} \times 100 \%$

$$
=23,07 \%
$$

Tahun $2017=\frac{1.664 .049 .635 .349}{7.012 .950 .012 .992} \times 100 \%$

$$
=23,72 \%
$$

Berdasarkan perhitungan menunjukan bahwa kemampuan kas asset dalam menunjang deposit dalam hal ini leabilitas tertinggi terjadi pada tahun 2015 yaitu $25,95 \%$, kemudian tahun 2016 sebesar 23,07\% dan di tahun 2017 sebesar 23,72\%.

\section{Investing Policy Ratio}

Investing Policy Ratio merupakan ratio yang digunakan untuk mengukur kemampuan bank dalam melunasi kewajibannya kepada para deposan dengan cara melikuidasi surat-surat berharga yang dimiliki. Pada umumnya jika situasi bank terjadi apabila mengalami kelebihan dan bank dapat menginvestasikan dana dalam bentuk surat-surat berharga yang sewaktu-waktu apabila bank membutuhkan dana, bank dapat menjual surat-surat berharga tersebut. 
Rasio ini dapat dihitung melalui rumus:

Investing Policy Ratio $=\frac{\text { securities }}{\text { total deposit }} \times 100 \%$

Berdasarkan data securitas berikut yang diperoleh dari laporan tahunan yang diterbitkan PT. Bank Pembangunan Daerah NTT maka dapat dihitung rasio ini menggunakan rumus di atas.

\section{Tabel 3}

Secuiritas PT. Bank Pembangunan Daerah NTT Tahun 2015-2018

\begin{tabular}{|l|c|c|c|}
\hline & $\mathbf{2 0 1 5}$ & $\mathbf{2 0 1 6}$ & $\mathbf{2 0 1 7}$ \\
\hline $\begin{array}{l}\text { Efek-Efek Untuk } \\
\text { Investasi }\end{array}$ & 973.465 .333 .196 & 569.182 .003 .239 & 551.040 .878 .014 \\
\hline $\begin{array}{l}\text { Efek-Efek Untuk } \\
\text { Dijual Kembali }\end{array}$ & - & - & $\mathbf{3 2 . 1 9 6 . 6 5 6 . 8 3 9}$ \\
\hline
\end{tabular}

Sumber: Laporan Pelaksanaan Bank NTT, 2018

Tahun $2015=\frac{973.465 .333 .196}{7.281 .384 .605 .250} \times 100 \%$

$=13,36 \%$

Tahun $2016=\frac{569.182 .003 .239}{6.795 .262 .466 .184} \times 100 \%$

$=8,37 \%$

Tahun $2017=\frac{583.237 .534 .853}{7.012 .950 .012 .992} \times 100 \%$

$=8,31 \%$

Berdasarkan hasil penilaian, maka didapatkan hasil kemampuan Bank NTT dalam melunasi kewajibannya kepada para deposan dengan cara melikuidasi suratsurat berharga yang dimiliki semakin tahun semakin menurun. Pada tahun 2015 kemampuan pemenuhan kewajiban sebesar 13,36\%, menurun sebesar 8,37\% pada tahun 2016 dan terus menurun pada tahun 2017 sebesar $8,31 \%$.

\section{Banking Ratio}

Rasio ini digunakan untuk mengukur tingkat likuiditas bank dengan membandingkan jumlah kredit yang disalurkan dengan jumlah deposit yang dimiliki. Rasio ini dapat dihitung dengan membandingkan total loans dengan total deposit

Banking Ratio $=\frac{\text { total loans }}{\text { total deposit }} \times 100 \%$ 
iE : Jurnal Inspirasi Ekonomi

Vol 4 No. 2 Juni 2019 | Isssn: 2503-3123 (Online)

Tabel 4

Total Loans PT. Bank Pembangunan Daerah NTT Tahun 2015-2017

\begin{tabular}{|l|c|c|c|}
\hline \multicolumn{1}{|c|}{ Kredit Yang Diberikan } & $\mathbf{2 0 1 5}$ & $\mathbf{2 0 1 6}$ & $\mathbf{2 0 1 7}$ \\
Pihak Berelasi & 13.140 .823 .560 & 7.446 .923 .513 & 17.311 .316 .958 \\
\hline Pihak Ketiga & 6.546 .469 .448 .832 & 7.289 .964 .941 .803 & 7.978 .081 .821 .398 \\
\hline Penyisihan Penurunan Nilai & $(89.312 .759 .627)$ & $(127.548 .224 .077)$ & $(158.981 .973 .714)$ \\
\hline Jumlah Bersih & 6.470 .297 .512 .765 & 7.169 .863 .641 .239 & 7.836 .411 .164 .642 \\
\hline Total & $\mathbf{6 . 4 8 3 . 4 3 8 . 3 3 6 . 3 2 5}$ & $\mathbf{7 . 1 7 7 . 3 1 0 . 5 6 4 . 7 5 2}$ & $\mathbf{7 . 8 5 3 . 7 2 2 . 4 8 1 . 6 0 0}$ \\
\hline
\end{tabular}

Sumber: Laporan Pelaksanaan Bank NTT, 2018

Berdasarkan data total loans di atas maka dapat dihitung Banking rasio sebagai berikut:

Tahun $2015=\frac{6.483 .438 .336 .325}{7.281 .384 .605 .250} \times 100 \%$

$$
=89,04 \%
$$

Tahun $2016=\frac{7.177 .310 .564 .752}{6.795 .262 .466 .184} \times 100 \%$

$$
=105,62 \%
$$

Tahun $2017=\frac{7.853 .722 .481 .600}{7.012 .950 .012 .992} \times 100 \%$

$$
=111,99 \%
$$

Berdasarkan perhitungan Banking Ratio maka didapat bahwa dari tahun 205 samapi tahun 2017 Bank NTT memilki kredit yang dibiayai oleh deposit semakin tinggi. Keadaan pada tahun 2016 dan 2017 menunjuakan situasi yang kurang baik karena jumlah kredit yang diberikan lebih tinggi dibandingkan dengan jumlah deposit yang dimiliki oleh pihak bank.

\section{Assets to Loan Ratio}

Rasio ini digunakan untuk mengukur jumlah kredit yang disalurkan dibandingkan dengan jumlah asset yang dimiliki oleh pihak bank.Semakin tinggi rasio ini menunjukan semakin rendah tingkat likuiditas bank. 
Tabel 5

Total Loans dan Total Assets PT. Bank Pembangunan Daerah NTT Tahun 2015-2017

\begin{tabular}{|l|c|c|c|}
\hline & $\mathbf{2 0 1 5}$ & $\mathbf{2 0 1 6}$ & $\mathbf{2 0 1 7}$ \\
\hline Kredit Yang Diberikan & & & \\
\hline Pihak Berelasi & 13.140 .823 .560 & 7.446 .923 .513 & 17.311 .316 .958 \\
\hline Pihak Ketiga & 6.546 .469 .448 .832 & 7.289 .964 .941 .803 & 7.978 .081 .821 .398 \\
\hline Penyisihan Penurunan Nilai & $(89.312 .759 .627)$ & $(127.548 .224 .077)$ & $(158.981 .973 .714)$ \\
\hline Jumlah Bersih & 6.470 .297 .512 .765 & 7.169 .863 .641 .239 & 7.836 .411 .164 .642 \\
\hline Total & $\mathbf{6 . 4 8 3 . 4 3 8 . 3 3 6 . 3 2 5}$ & $\mathbf{7 . 1 7 7 . 3 1 0 . 5 6 4 . 7 5 2}$ & $\mathbf{7 . 8 5 3 . 7 2 2 . 4 8 1 . 6 0 0}$ \\
\hline JUMLAH ASET & 9.551 .162 .232 .305 & 9.597 .926 .603 .279 & 10.379 .174 .422 .657 \\
\hline
\end{tabular}

Sumber: Laporan Pelaksanaan Bank NTT, 2018

Tahun $2015=\frac{6.483 .438 .336 .325}{9.551 .162 .232 .305} \times 100 \%$

$$
=67,88 \%
$$

Tahun $2016=\frac{7.177 .310 .564 .752}{9.597 .926 .603 .279} \times 100 \%$

$$
=74,78 \%
$$

Tahun $2017=\frac{7.853 .722 .481 .600}{10.379 .174 .422 .657} \times 100 \%$

$$
=75,67 \%
$$

Bersasarkan hasil perhitungan di atas, maka dapat dilihat bahwa jumlah kredit yang diberikan dibandingkan jumlah asset setiap tahunnya mengalami peningkatan. Hal ini menunjukan tingkat likuiditas bank NTT setiap tahunnya memiliki tren menurun.

\section{Cash Ratio}

Rasio ini digunakan untuk mengukur kemampuan bank dalam kewajiban atau hak deposan yang harus segera dibayar dengan asset likuid atau kas dan setara kas yang dimiliki oleh bank.

Cash Ratio $=\frac{\text { liquid assets }}{\text { Short term borrowing }} \times 100 \%$

Tahun $2015=\frac{1.889 .760 .702 .199}{8.056 .342 .151 .575} \times 100 \%$

$$
=23,46 \%
$$

Tahun $2016=\frac{1.568 .022 .804 .618}{7.928 .941 .867 .459} \times 100 \%$

$$
=19,78 \%
$$


Tahun $2017=\frac{1.664 .049 .635 .349}{8.569 .714 .579 .9627} \times 100 \%$

$$
=19,42 \%
$$

Berdasarkan perhitungan di atas, maka selama tahun 2015 samapi tahun 2017 PT. Bank NTT mampu melunasi kewajibannya dengan harta likuidnya. Hal ini ditunjukan dengan cash ratio yang berada diatas $10 \%$. Hal ini menunjukan jumlah asset mampu melunasi keajibannya yang harus degera dibayarkan.

\section{Loan To Deposit Ratio}

Rasio ini untuk mengukur komposisi jumlah kredit yang diberikan dibandingkan dengan jumlah dana masyarakat atau modal sendiri yang digunakan. Batas maksimum berdasarkan peraturan pemerintah adalah $110 \%$.

Loan To Deposit Ratio =

$\frac{\text { total loan }}{\text { total deposittequity }} \times 100 \%$

Tahun $2015=$

$\frac{6.483 .438 .336 .325}{7.281 .384 .605 .250+1.494 .820 .080 .730} \times 100 \%$

$=73,88 \%$

Tahun $2016=$

$\frac{7.177 .310 .564 .752}{6.795 .262 .466 .184+1.668 .984 .735 .820} \times 100 \%$

$=84,80 \%$

Tahun $2017=$

$\frac{7.853 .722 .481 .600}{7.012 .950 .012 .992+1.809 .459 .842 .685} \times 100 \%$
$=89,02 \%$

Perhitungan di atas menunjukan bahwa dari tahun 2015 sampai tahun 2017 PT. Bank NTT masih dalam batas wajar dalam pemberian kredit. Hal ini ditunjukan dengan ratio LDR yang berkisaran antara 73,88\% sampai $89,02 \%$

\section{Rasio Solvabilitas.}

Rasio Ini digunakan untuk mengukur kemampuan Bank dalam mencari sumber dananya untuk membiaya kegiatan dari bank itu sendiri.Rasio ini merupakan alat 
yang digunakan untuk mengukur kekayaan bank dan melihat efisiensi pengelolaan bank.

\section{Primari Ratio}

Rasio ini digunakan untuk mengukur apakah permodalan yang dimiliki sudah memadai.

$$
\text { Primary Ratio }=\frac{\text { equity Capital }}{\text { Total aktiva }} \times 100 \%
$$

Tahun $2015=\frac{1.494 .820 .080 .730}{9.551 .162 .232 .305} \times 100 \%$

$$
=15,65 \%
$$

Tahun $2016=\frac{1.668 .984 .735 .820}{9.597 .927 .603 .279} \times 100 \%$

$$
=17,39 \%
$$

Tahun $2017=\frac{1.809 .459 .842 .685}{10.379 .174 .422 .657} \times 100 \%$

$$
=17,43 \%
$$

Berdasarkan perhitungan di atas maka dapat dilihat kemampuan permodalan yang dimiliki dari tahun ke tahun semakin meningkat.

\section{Rasio kecukupan modal}

Rasio ini digunakan untuk mengukur sejauh mana modal dapat menutupi pinjaman ditambah securitas yang dimiliki.

Primary Ratio $=\frac{\text { equity-fixd assets }}{\text { total loans+securitas }} \times 100 \%$

\section{Tahun 2015}

$=\frac{1.494 .820 .080 .730-111.289 .548 .562}{6.483 .438 .336 .325+973.465 .333 .196} \times 100 \%$

$=18,55 \%$

\section{Tahun 2016}

$=\frac{1.668 .984 .753 .820-133.392 .057 .312}{7.169 .863 .641 .239+569.182 .003 .239} \times 100 \%$

$=19,84 \%$

Tahun 2017

$=\frac{1.809 .459 .842 .685-141.962 .675 .409}{7.978 .081 .821 .398+551.040 .878 .014+31.196 .565 .839} \times 100 \%=20,82 \%$ 
Berdasarkan perhitungan di atas maka dapat dilihat kemampuan modal Bank NTT dalam menutupi pinjamannya dan securitas.Dari tahun 2015 sampai dengan tahun 2017 kemampuannya terus meningkat.

\section{Debt Ratio}

Rasio ini digunakan untuk mengukur seberapa besar asset yang ada dibiayai oleh hutang yang dimiliki bank.

Debt Ratio $=\frac{\text { total hutang }}{\text { Total aktiva }} \times 100 \%$

Tahun $2015=\frac{8.056 .342 .151 .575}{9.551 .162 .232 .305} \times 100 \%$

$$
=84,35 \%
$$

Tahun $2016=\frac{7.928 .941 .867 .459}{9.597 .926 .603 .279} \times 100 \%$

$$
=82,61 \%
$$

Tahun $2017=\frac{8.569 .714 .579 .9627}{10.379 .174 .422 .657} \times 100 \%$

$$
=82.57 \%
$$

Berdasarkan perhitungan di atas dapat dilihat bahwa sebagian besar assets yaitu diatas $80 \%$ dibiayai melalui ekuitas.

\section{Debt Equity Ratio}

Rasio ini dipakai guna mengetahui perbandingan antara sumber dana yang berasal dari hutang dan modal sendiri

DER $=\frac{\text { Total Hutang }}{\text { equitas }}$

Tahun $2015=\frac{8.056 .342 .151 .575}{1.494 .820 .080 .730}$

$$
=5,38 \mathrm{kali}
$$

Tahun $2016=\frac{7.928 .941 .867 .459}{1.668 .984 .753 .820} \times 100 \%$

$$
=4,75 \mathrm{kali}
$$

Tahun $2017=\frac{8.569 .714 .579 .9627}{1.809 .459 .842 .685}$

$$
=4,73 \mathrm{kali}
$$

Berdasarkan perhitungan diatas dapat dilihat bahwa rasio hutang terhadap equitas cukup tinggi.Hal ini menunjukan bahwa ada kemungkinan bank tidak dapat menghasilkan uang yang cukup untuk memenuhi kewajiban hutangnya. 


\section{Risk Asets Ratio}

Rasio ini digunakan untuk mengukur kemungkinan penurunan resiko assets.

Risk Assets Ratio =

$$
\frac{\text { equity capital }}{\text { total assets-cash assets-securities }} \text { X100\% }
$$

Tahun2015 $=\frac{1.494 .820 .080 .730}{9.551 .162 .232 .305-6.902 .400,838-973,465,333,196} \times 100 \%$

$$
=17,34 \%
$$

Tahun $2016=$

$\frac{1.668 .984 .753 .820}{9.597 .926 .603 .279-1.568 .022 .804 .618-569.182 .003 .239} \times 100 \%$
$=22,37 \%$

Tahun $2017=$

$\frac{1.809 .459 .842 .685}{10.379 .174 .422 .657-1.664 .049 .635 .349-1.809 .459 .842 .685} \times 100 \%$
$=26,20$

Perhitungan di atas menunjukan bahwa penurunan resiko terhadap asset yang dimiliki Bank terus mengalami peningkatan artinya kemampuan bank dalam hal mengurangi terjadinya resiko terus meningkat dari tahun ke tahun.

\section{Rasio Rentabilitas}

Rasio ini disebut juga sebagai rasio profitabilitas, yaitu rasio yang digunakan untuk mengukur kemampuan perusahaan dalam memperoleh laba atau keuntungan.

\section{Gross Profit Margin}

Merupakan gambaran dari prestasi atau kemampuan laba dari kegiatan murni yang ada di bank setelah dikurangi dengan biaya-biaya.

Gros Profit Margin =

$\frac{\text { Operating income-operating expanse }}{\text { Operating income }} \times 100 \%$

Tahun $2015=$

$\frac{931.324 .491 .115-(542.063 .978 .853)}{931324.491 .115} \times 100 \%$

$$
=41,80 \%
$$

Tahun $2016=$

$\frac{956.046 .626 .111-(679.180 .953 .583)}{956.046 .626 .111} \times 100 \%$ 


$$
=28,96 \%
$$

Tahun $2017=$

$$
\begin{aligned}
& \frac{1.010 .770 .168 .315-(667.441 .152 .367)}{1.010 .770 .168 .3159627} \times 100 \% \\
& =33,97 \%
\end{aligned}
$$

Jika dilihat dari hasil perhitungan diatas maka persentasi laba yang dihasilkan Bank dari kegiatan usaha murni berada diatas $20 \%$, dan cenderung meningkat.Hal ini menunjukan bank sudah cukup mampu dalam menghasilkan laba.

\section{Net Profit Margin}

Merupakan rasio yang digunakan untuk mengukur laba bersih sesudah pajak lalu dibandingkan dengan volume penjualan

Net Profit Margin =

$\frac{\text { Net Income }}{\text { operating Ineome }} \mathrm{X} 100 \%$

Tahun $2015=\frac{258.228 .698 .290}{931.324 .491 .115} \times 100 \%$

$$
=22,73 \%
$$

Tahun $2016=\frac{233.844 .094 .000}{956.046 .626 .111} \times 100 \%$

$$
=23,44 \%
$$

Tahun $2017=\frac{246.335 .525 .005}{2.020 .770 .268 .325} \times 100 \%$

$$
=24,37 \%
$$

Bank Pembangunan Daerah NTT jika dilihat dari perhitungan di atas sudah mampu dalam menghasilkan net income atau laba baersih dari kegiatan atau volume penjualan kegiatan operasi pokoknya.Hal ini dapat dilihat dari rasio net profit yang berada diatas $20 \%$.

\section{Net Income total Assets}

Rasio ini digunakan untuk mengukur kemampuan manajemen dalam memperoleh profitabilitas dan efesiensi manajerial secara keseluruhan.

Net Income total assets $=$

$\frac{\text { net income }}{\text { Total assets }} \mathrm{X} 100 \%$

Tahun $2015=\frac{258.228 .698 .290}{9.551 .162 .232 .305} \times 100 \%$

$$
=2,70 \%
$$


Tahun $2016=\frac{233.844 .094 .000}{9.597 .926 .603 .279} \times 100 \%$

$=2,44 \%$

Tahun $2017=\frac{246.335 .525 .005}{10.379 .174 .422 .657} \times 100 \%$

$=2,37 \%$

Berdasarkan perhitungan dapat dilihat bahwa kemampuan manajemen dalam memperoleh profit rata-rata berada pada $2 \%$.

\section{Penutup}

\section{Kesimpulan}

1. Analisis rasio Likuiditas menunjukan kinerja yang baik ditunjukan oleh PT. Bank NTT selama tiga tahun, artinya Bank NTT sudah cukup mampu dalam membayar semua kewajibannya kepada deposan

2. Berdasarkan hasli analisis rasio solvabilitas selama tiga tahun menunjuka PT. Bank NTT mampu membayar kewajiban jangka panjang dan jangka pendeknya dengan baik.

3. Hasil analisis rasio rentabilitas, menunjukan Bank NTT memiliki kinerja yang baik dalam memanajemen labanya, yaitu kemampuannya untuk memperoleh laba selama tiga tahun.

\section{Saran}

1. Bagi pihak manajemen PT. Bank Pembangunan Daerah NTT agar lebih meningkatkan kemampuan keuangannya baik jangka panjang mauupun jangka pendek sehingga dapat meningkatkan laba pada periode yang mendatang

2. Bagi peneliti lain agar dapat melengkapi penilai kinerja PT. Bank NTT yang lebih menyeluruh. 
iE : Jurnal Inspirasi Ekonomi Vol 4 No. 2 Juni 2019 | Isssn: 2503-3123 (Online)

\section{DAFTAR PUSTAKA}

Dahlan, Siamat. 2004. Manajemen Lembaga Keuangan. Edisi Keeepat. Lembaga Penerbitan Fakultas Ekonomi Universitas Indonesia

Fahmi,Irham. 2011.Analisis Kinerja Keuangan Panduan Bagi Akademisi, Manajer, Dan Investor Untuk Menilai Dan Menaganisis Bisnis Dari Aspek Keuangan. Bandung:Alfabeta.

Jumingan. 2006. Analisis Laporan Keuangan. Jakarta: Aksara.

Kasmir. 2018. Analisis Laporan Keuangan. Jakarta: Rajawali Press

Munawir, S. 2014. Analisis Laporan Keuangan. Yogyakarta: Liberty

Wibisono,Andri. 2012. Analisis Kinerja Keuangan Pada PT. Bank Muamalat Indensia, TBK Periode 2005-2009. Jurnal Administrasi Bisnis. Inversitas Diponegoro. Akses Tanggal 3 November 2018

PT. Bank Pembangunan Daerah Nusa Tenggara Timur, Laporan Pelaksanaan Good Corparate Governance. Kupang: 2018 